\author{
초위성체 유전표지를 이용한 한우와 외래품종간의 유전적 변이와 \\ 유연관계 분석 \\ 오재돈* · 공홍식* . 이제현* . 양대용** . 전광주* . 이학교* \\ 한경대학교 유전정보연구소*, 축산물등급판정소**
}

\title{
Genetic Variation and Relationships of Korean Cattle (Hanwoo) and Foreign Breeds Using Microsatellite Markers
}

\author{
Jae Don Oh*, Hong Sik Kong*, Jae Hyeon Lee*, Dae Yong Yang**, Gwang Joo Jeon* \\ and Hak Kyu Lee* \\ Genomic Informatics Center, Hankyong National University, Korea*, \\ Animal Products Grading Service, Korea**
}

\begin{abstract}
The purpose of this study was to assess the genetic variation and establish the relationship amongst Hanwoo, Angus and Holstein breed. The genetic characteristics and variability within Hanwoo (300), Angus (80) and Holstein (50) were estimated on the basis of relationships determined using the 10 kinds of microsatellite, which is located on different chromosomes. Frequencies of microsatellites markers were used to estimate heterozygosities, polymorphic information content (PIC) and genetic distances. The PICs ranged from 0.604 to 0.872 (Hanwoo), from 0.562 to 0.812 (Angus) and from 0.471 to 0.828 (Holstein). Observed heterozygosity and PIC of Hanwoo are the highest among the analyzed breeds. Additionally, Estimates of genetic distance can be utilized to identify genetic relationships between Hanwoo and the other breed. Genetic distances (0.233) between Hanwoo and Angus was lower than distances between Hanwoo and Holstein (2.283). Also, Genetic distances between Angus and Holstein was shown for $(2,400)$. The other side, each individuals were not ramified to different group and were spread evenly in phylogenetic dendrogram about all the populations.
\end{abstract}

(Key words : Microsatellite, Genetic distance, Hanwoo)

$$
\text { I. 서 론 }
$$

최근 한우 산업은 쇠고기시장 개방의 확대와 광우병 파동 등에 따른 식품안전성에 대한 소 비자 욕구의 증대 등 변화되는 시장 환경에 대 응하기 위해 한우 산업구조의 개선이 필요한 시점이다. 이를 위해 한우 산업의 경쟁력제고, 부가가치 창출 및 안전한 쇠고기 생산과 차별 화 마케팅을 위해 유전특성에 근거한 우수유전
자원의 확보 및 개량이 매우 시급하다. 특히 식품안전성에 대한 소비자의 욕구가 높아지고 있어 이에 대한 신뢰성의 확보가 매우 중요한 사안으로 대두되고 있다. 최근에는 DNA 정보 를 한우 원산지 추적시스템에 도입하여 사육단 계부터 도축 및 가공 유통단계까지 원산지 검 증에 활용하고자 하는 연구가 시도되고 있다 (임 등, 2005).

세계적으로 1990년대 중반부터 가축집단의

Corresponding author : H. K. Lee, Genomic Information Center, Hankyong National University, Ansung 456-749, Korea. Tel : +82-31-670-5330, Fax : +82-31-675-5331, E-mail : breedlee@empal.com 
유전적 다양성, 유전적 특성 등의 집단의 유전 적 구조분석과 혈통의 정확도를 확인하기 위한 개체식별 및 친자확인 등의 목적을 위하여 초 위성체 유전표지를 널리 이용하여 왔다 (Arranz 등, 1996; Blott 등, 1999; Lee 등, 2002). 초위성 체 유전표지는 생물체의 게놈에 존재하는 단순 염기서열들의 수많은 반복들을 지칭하는 것으 로, 짧고 단순하며 반복적인 염기형태로 척수 동물 genome 전체에 걸쳐 풍부하게 분포되어 있다(Litt와 Luty, 1989; Baker 등, 1997; Peelman 등, 1998; Martin 등, 1999; Li 등, 2000; Bjornstad 등, 2003). 초위성체 유전표지는 세대 당 $10^{-4}$ 이상의 높은 돌연변이율을 가지며 집 단 내에서 뿐 아니라 개체수준에서 특이적인 다형성과 공우성을 나타내게 되어 인간을 비롯 한 동물과 식물 등에 유전적 다양성에 대한 정 보는 물론 유전자지도 작성에 유용한 도구로 사용되어 지고 있다. 최근 국가차원에서 추진 중에 있는 DNA를 이용한 한우 원산지 검증시 스템에서도 개체의 동일성 검증을 위해 국제동 물유전학회(ISAG)에서 추천된 초위성체 유전 표지를 활용하고 있다.

쇠고기 수입개방 확대에 따라 다양한 외래품 종의 수입이 확대 될 것이다. 이는 한우가 아 닌 수입 생우 또는 타 육우품종이 한우로 둔갑 되어 판매될 가능성이 있다. 따라서 한우 원산 지 검증 시스템의 활용성과 신뢰성을 높이기 위해서는 한우의 유전적 특성 및 차별성에 대 한 체계적인 분석과 이에 필요한 적정한 DNA 정보의 활용에 필요한 기술적 접근이 필요하 다. 본 연구는 현재 수입육에서 높은 비중을 차지하고 있는 엥거스 품종과 국내산 비육우로 사육되어 출하되고 있는 홀스테인 품종을 대조 집단으로 설정하여 한우의 유전적 특성과 유전 적 차별성을 규명하기 위해 수행하였다.

\section{ㅍ. 재료 및 방법}

\section{1. 공시재료}

공시재료로는 전국 9 개의 브랜드 집단에서 사육된 한우 수소 300 두를 대상으로 도축시 조
직을 채취하였으며, 앵거스집단은 생우로 수입 된 이후 도축시 80 두의 조직을 채취하였고, 홀 스테인 집단은 축산과학원에서 사육되고 있는 집단에서 임의서 50 두를 선발하여 혈액을 이용 하였다. 이렇게 수집된 조직과 혈액에서 genomic $\mathrm{DNA}$ 를 분리하여 본 실험에 공시재료로 이용하 였다.

\section{2. 초위성체 유전표지의 선정 및 $\mathrm{PCR}$ 증폭 조건}

본 연구는 국제동물유전학회 (ISAG)에서 축 우용 개체식별을 위해 사용되도록 권장하여 국 제적으로 널리 활용되고 있는 초위성체 유전표 지 (microsatellite)중 10종을 선택하여 사용하였 다. 이들 각각의 초위성체 유전표지는 서로 다 른 염색체 상에 존재하며 (BM1824: 1번 염색체, BM2113: 2번 염색체, ETH10: 5번 염색체, ETH225: 9번 염색체, ETH3: 19번 염색체, SPS115: 15번 염색체, TGLA122: 21번 염색체, TGLA126: 20 번 염색체, TGLA227: 18번 염색체, TGLA53: 16번 염색체) 이들 초위성체 유전표지의 개체 별 유전자형을 분석하여 활용하였다. 초위성체 유전표지의 유전자형을 결정하기 위하여 초위 성체 유전표지의 색상과 대립유전자의 크기별 분포 등을 고려하여 multiplex PCR을 수행하였 다. GeneAmp 9700 (Applied Biosystems)에서 각 반응액의 총량을 $15 \mu l$ PCR reaction으로 하고 약 10 100 ng/ $\mu$ template DNA, $20 \mathrm{ng}$ each primer, $1.25 \mathrm{mM}$ each of dNTP, $0.5 \mathrm{U}$, of Taq DNA polymerase (AmpliTaq Gold with GeneAmp) 과 $3 \mu$ 10X PCR buffer $(100 \mathrm{mM}$ Tris- $\mathrm{HCl}, \mathrm{pH}$ 8.3, $500 \mathrm{mM} \mathrm{KCl}, 0.01 \%$ gelatin, $0.25 \%$ nonidet $\mathrm{P} 40$ and $20 \mathrm{mM} \mathrm{MgCl}_{2}$ )를 이용하여 $95^{\circ} \mathrm{C}$ 에서 10 분간 첫 반응을 시작하여, $94^{\circ} \mathrm{C}$ 에서 45 초, 각 microsatellite marker의 조건 따라 $55 \sim 61^{\circ} \mathrm{C}$ 에서 45 초, $72^{\circ} \mathrm{C}$ 에서 1 분으로 31 회 반복반응을 실시 하고 신장 반응은 $72^{\circ} \mathrm{C}$ 에서 60 분간 실시하고 마지막으로 $25^{\circ} \mathrm{C}$ 에서 2 시간 실시하여 종료하였 다.

\section{Microsatellite 유전자형 분석}


$\mathrm{PCR}$ 을 수행한 후 증폭산물들을 2\%의 agarose gel에 전기영동하고 그 결과에 따라 희석배율 을 정하고 희석배율에 따라 Formamide를 이용 하여 희석하고, 다시 Formamide와 Genescan ${ }^{\mathrm{TM}}$ $-500 \mathrm{RoX}^{\mathrm{TM}}$ standard를 잘 혼합하여 $\mathrm{ABI} 3130 \mathrm{XL}$ DNA sequencer (Applied Biosystems)를 사용하였 다. Foundation Data Collection (version 3.0)을 사 용하여 plate manage 및 run schedule을 정하고 PCR 단편들의 크기를 3차원 최소자승법 (Third order least squares method)으로 분석하였고, Genemapper (version 3.7)를 이용하여 초위성체 유전표지별 대립유전자들의 정확한 크기를 결 정하였다.

\section{4. 통계분석 및 집단간 유연관계 분석}

초위성체 유전표지별 유전자형 data를 Twocolumn diploid format의 file로 변환시킨 뒤 MS Tool Kit S/W (Park, 2000, in personnel)를 이용 하여 각 좌위별 관측 이형질성 (Observed heterozygosity), 대립유전자의 빈도 및 품종별 대립 유전자의 빈도를 산출하였다. 품종별 유 전적 다양성을 알아보기 위해 Hardy_Weinberg 법칙을 이용한 초위성체 유전표지에 따른 기대 이형질성 (expected heterozygosity) 및 유전자 좌 위의 다형성 정보량 (polymorphism information content: PIC) (David botstein 등, 1980)을 계산하 였다.

$$
\begin{aligned}
\text { Het }_{\mathrm{E}} & =1-\left(\sum_{i=1}^{k} P^{2}{ }_{i}\right) \\
\mathrm{PIC} & \left.=1-\sum_{i=1}^{k} P_{i}^{2}\right)-\sum_{i=1}^{k-1} \sum_{j=i+1}^{k} 2 \mathrm{Pi}^{2} \mathrm{Pj}^{2}
\end{aligned}
$$

$k$ : 대립유전자의 수

$\mathrm{P}_{\mathrm{i}}, \mathrm{P}_{\mathrm{j}} \mathrm{i}$ 번째와 $\mathrm{j}$ 번째의 대립유전자의 빈도

$\mathrm{Het}_{\mathrm{E}}$ : 기대이형질성 (expacted heterozygosity)

$\mathrm{PIC}$ : 다형성 정보량 (polymorphism information content)

품종간 유연관계 분석을 위해 sample number
의 보정을 통한 Nei 등 (1983)의 방법을 이용한 DISPAN program(Ota, 1993)을 사용하였으며, Neighbor-Joining (NJ) method(Saitou와 Nei, 1987) 를 이용하여 genetic distances를 추정하여 이를 근거로 한 phylogenetic tree를 작성하였다. 또한 simple allele-sharing 측정 수준을 통하여 개체별 대립유전자의 빈도를 근거로 집단유전학적 분 석 프로그램인 Phylip v.3.65를 이용하여 전체집 단의 개체별 유전적거리의 추정치를 근거로 하 여 모든 개체간의 Neighbor-Joining phylogenetic dendrogram를 작성하였다.

\section{III. 결과 및 고찰}

한우와 외래품종간의 유전적 특성을 규명하 기 위해 한우 300 두, 앵거스 80 두 그리고 홀스 테인 50 두를 대상으로 10 개의 초위성체 유전표 지를 분석하였다. 연구에 활용된 10 개의 초위 성체 유전표지는 현재 한우 생산이력시스템에 활용 중에 있으며 분석 결과 한우, 앵거스 그 리고 홀스테인 집단의 기대이형질성 (expected total heterozygosity), 관측된 이형질성 (observed heterozygosity) 및 유전적 다형정보력 (polymorphism information content; PIC)를 Table 1에 제시하였다.

한우집단에서의 기대이형질성과 관측이형질 성의 평균값은 각각 $0.772,0.733$ 으로 나타났다. TGLA126의 경우 가장 낮은 기대이형질성 (0.646)을 나타냈으며 TGLA53은 가장 높은 기 대이형질성 (0.883)을 보였다. 앵거스 단에서의 기대이형질성과 관측이형질성의 평균값은 각각 $0.759,0.707$ 로 나타났다. 기대이형질성의 가장 높은 값은 TGLA227(0.837)이고 반대로 가장 낮은 값은 $\mathrm{ETH} 10$ (0.626)으로 나타났으며 관측 된 이형질성의 가장 높은 값은 $\mathrm{BM} 2113$ (0.848) 이고 가장 낮은 값은 TGLA53 (0.564)으로 나타 났다. 홀스테인집단에서의 기대이형질성과 관 측된 이형질성의 평균값은 각각 $0.741,0.720$ 으 로 나타났다. $\mathrm{ETH} 10$ 은 가장 높은 기대이형질 성 (0.855)을 나타냈고 ETH3은 가장 낮은 기대 이형질성 (0.506)을 나타냈으며 관측이형질성의 가장 높은 것과 낮은 것은 각각 $\mathrm{BM} 2113(0.840)$ 
Table 1. Characterization of 10 microsatellite loci analyzed in three populations.

\begin{tabular}{|c|c|c|c|c|c|c|c|c|c|}
\hline \multirow{2}{*}{ Loci } & \multicolumn{3}{|c|}{$\operatorname{HAN}(11.4)^{\mathrm{a}}$} & \multicolumn{3}{|c|}{ ANG(8.9) ${ }^{\mathrm{a}}$} & \multicolumn{3}{|c|}{$\operatorname{HST}(7.5)^{\mathrm{a}}$} \\
\hline & Exp. Hz & Obs. Hz & PIC & Exp. Hz & Obs. Hz & PIC & Exp. Hz & Obs. Hz & PIC \\
\hline BM1824 & 0.710 & 0.707 & 0.666 & 0.748 & 0.712 & 0.702 & 0.834 & 0.795 & 0.805 \\
\hline BM2113 & 0.715 & 0.757 & 0.675 & 0.780 & 0.848 & 0.745 & 0.756 & 0.840 & 0.707 \\
\hline ETH10 & 0.772 & 0.757 & 0.738 & 0.626 & 0.637 & 0.562 & 0.855 & 0.833 & 0.828 \\
\hline ETH225 & 0.656 & 0.673 & 0.607 & 0.775 & 0.725 & 0.734 & 0.730 & 0.775 & 0.689 \\
\hline ЕTH3 & 0.753 & 0.720 & 0.711 & 0.698 & 0.712 & 0.658 & 0.506 & 0.510 & 0.471 \\
\hline SPS115 & 0.840 & 0.754 & 0.817 & 0.806 & 0.697 & 0.775 & 0.821 & 0.820 & 0.791 \\
\hline TGLA122 & 0.868 & 0.791 & 0.852 & 0.787 & 0.662 & 0.752 & 0.780 & 0.708 & 0.737 \\
\hline TGLA126 & 0.646 & 0.670 & 0.604 & 0.722 & 0.775 & 0.672 & 0.735 & 0.571 & 0.680 \\
\hline TGLA227 & 0.872 & 0.838 & 0.859 & 0.837 & 0.737 & 0.812 & 0.681 & 0.687 & 0.617 \\
\hline TGLA53 & 0.883 & 0.659 & 0.872 & 0.808 & 0.564 & 0.785 & 0.705 & 0.660 & 0.655 \\
\hline Average & 0.771 & 0.732 & 0.740 & 0.758 & 0.706 & 0.719 & 0.740 & 0.719 & 0.698 \\
\hline
\end{tabular}

HAN : Hanwoo, ANG : Angus, HST : Hostein

Exp. $\mathrm{Hz}$ : expected total heterozygosity

Obs. $\mathrm{Hz}$ : observed heterozygosity

PIC : polymorphic information content

a : average number of alleles which is appeared in each breed.

과 ETH3 (0.510)으로 나타났다. 한우집단과 앵 거스집단에서 TGLA53의 관측된 이형질성은 가 장 낮은 것으로 나타났으며 홀스테인집단의 경 우도 비교적 낮은 것을 확인 할 수 있었다. 반 면 BM2113의 경우는 앵거스집단과 홀스테인집 단에서 가장 높은 관측 이형질성을 나타냈으나 한우집단에서는 상대적으로 낮게 나타났다.

유전자 다형성의 정보량을 보여주는 PIC 값 에서 한우집단은 0.604 (TGLA126)에서 0.872 (TGLA53), 앵거스집단은 0.562 (ETH10)에서 0.812 (TGLA227) 그리고 홀스테인집단은 0.471 (ETH3) 에서 0.828 (ETH10)로 추정 되었다. TGLA126의 경우 PIC 값이 0.604로 한우집단에서 가장 낮 은 것으로 나타났으며 다른 두 집단에서도 상 대적으로 낮은 것으로 나타났다. TGLA53은 한 우집단에서 0.872 로 나타나 전체의 PIC 값 중 에 가장 높은 것으로 검출된 반면 홀스테인집 단에서는 0.655 로 다소 낮은 것으로 검출되었 다. ETH10은 앵거스집단에서 0.562로 가장 낮 게 나타난 반면, 홀스테인집단에서는 0.828 로 가장 높은 것으로 나타났다.

품종간의 유전적 유연관계를 알아보기 위해
각 초위성체 유전표지별 대립유전자의 빈도를 산출하여 이를 근거로 집단간의 보정을 통한 Nei 등 (1983)의 방법을 이용하는 DISPAN program을 활용하여 유전적 거리에 대한 추정 값을 계산하였다 (Table 2). 한우집단은 엥거스 집단과의 유전적 거리가 $0.233 \pm 0.054$ 으로 홀스 테인집단 $(2.183 \pm 0.658)$ 과의 거리에 비해 상당 히 가까운 것으로 나타났으며, 앵거스 집단과 홀스테인집단간의 유전적 거리 역시 $0.2400 \pm$ 0.727 로 상당히 먼 것으로 나타났다. 이렇게 분 석된 genetic matrix를 근거로하여 NJ (NeighborJoining) (Saitou and Nei, 1987)의 clustering 방법 을 이용하여 그림 1 에 품종별 분지도를 작성하 여 제시하였다.

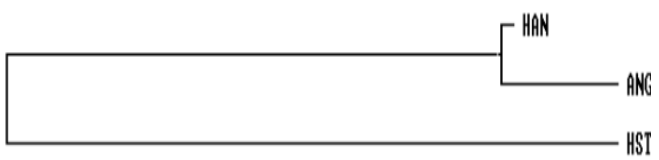

Fig. 1. The NJ phylogenetic tree showing the genetic relationships among 3 breeds of Hanwoo, Angus and Holstein. 
분석된 품종별 유전적 구조에 따라 각 개체 들이 품종내 유전적 집락분석 확인을 위해, simple allele-sharing 측정 수준을 통하여 개체별 대립유전자의 빈도를 근거로 각 개체들간의 유 전적 거리에 대한 추정값을 계산하였으며 이를 바탕으로 유전분석 프로그램 중 하나인 Phylip v.3.0을 이용하여 개체별 분지도 작성을 위한 tree file을 작성하였다. 작성된 tree file은 TreeView 프로그램을 이용하여 개체별 NeighborJoining phylogenetic dendrogram을 작성하여 그 림 2 에 제시하였다 그림 1 에 제시한 품종별 분 지도와 마찬가지로 군집을 이루어 각 품종별로

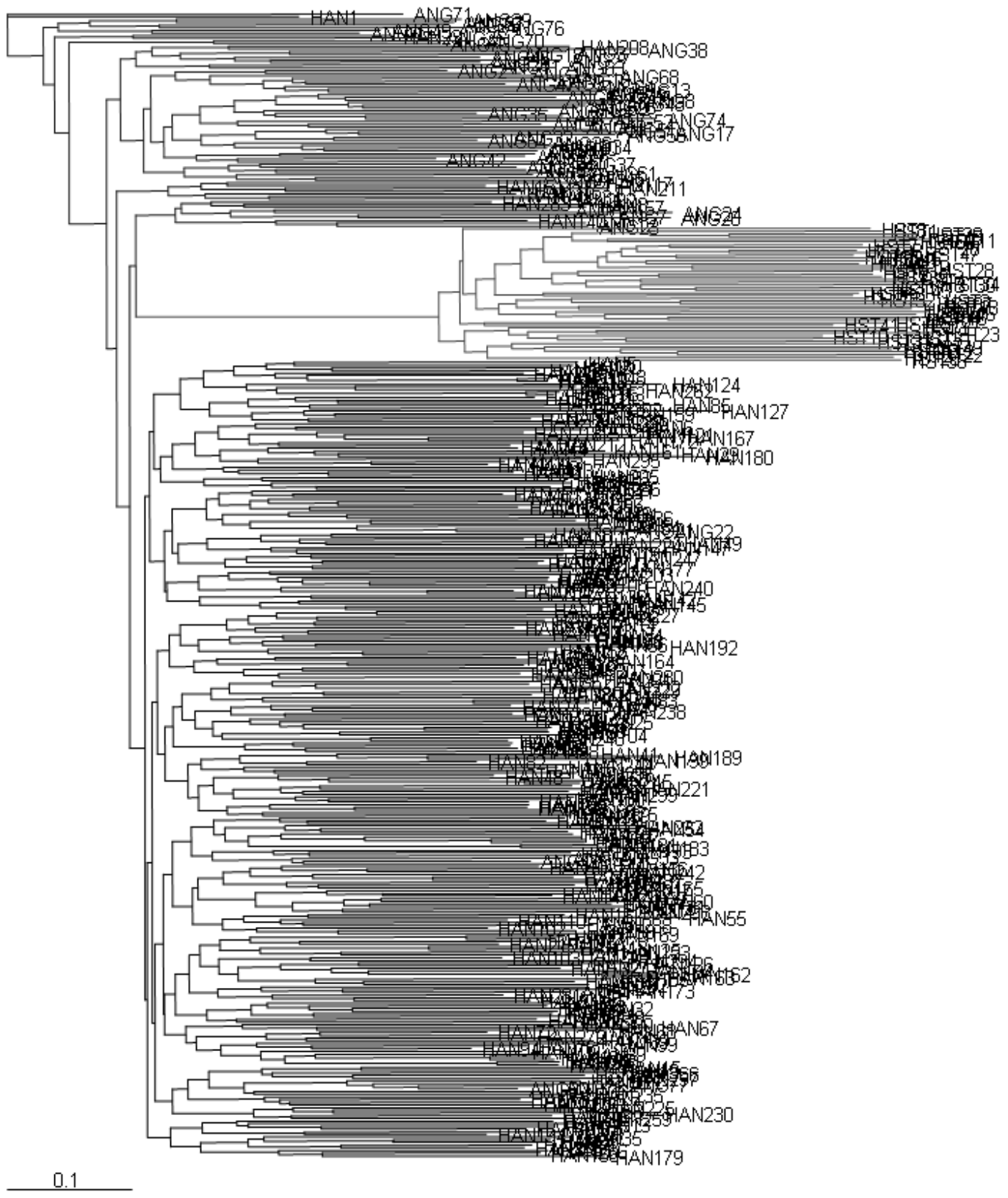

Fig. 2. Neighbor-Joining phylogenetic dendrogram on Hanwoo, Angus and Holstein. Black line : Hanwoo, Blue line: Angus, Red line : Holstein. 
개체들이 분포하고 있음을 확인할 수 있었다. 한우와 앵거스의 몇몇의 개체들은 서로의 품종 들이 군집을 이루고 있는 사이사이에 존재하는 것을 확인 할 수 있었는데 이러한 유전적 배경 으로 인해 홀스테인에 비해 한우와 앵거스의 유전적 거리가 상대적으로 가까운 것으로 추정 된 것으로 사료된다. 이러한 결과는 몇몇 개체 를 제외하면 한우, 앵거스, 홀스테인 집단들이 유전적으로 명확히 구분이 되어 있음을 확인 할 수 있다.

본 연구에서는 유전적 다양성 및 외래품종집 단간의 유연관계 등의 평가를 위해 10 개의 상 염색체에 존재하는 10 개의 초위성체 유전표지 를 이용하여 소 품종집단별 유전적 다양성의 척도인 이형질성, 유전적 거리 및 유연관계 등 을 추정하여 보았다. 각 집단 간의 이형질성 분석결과를 살펴보면, 한우집단이 0.733 , 앵거 스 집단이 0.707 그리고 홀스테인 집단이 0.720 으로 나타났으며 이는 Vasconcellos 등 (2003)이 보고한 앵거스 집단의 이형질성 (0.653)과 Hansen 등 (2002)의 연구에서 보고된 홀스테인 집단의 이형질성 (0.690) 보다 높게 나타났음을 확인하 였다. Vasconcellos 등 (2003)과 Hansen 등(2002) 의 보고에 비해 본 연구에서 이형질성이 다소 높게 나타났는데 이는 각 연구에 활용된 집단 과 유전표지가 서로 다르기 때문에 나타난 차 이로 해석된다. 또한 윤 등 (2005)의 연구에서 한우 집단의 이형질성은 0.682로 앵거스 집단 과 홀스테인 집단의 이형질성 (각 0.561, 0.645) 보다 높게 나타났다. 이는 본 연구 결과에서도 확인된 바와 같이 한우집단이 앵거스와 홀스테 인 집단에 비해 높은 이형질성을 나타내고 있 어 윤 등(2005)의 결과와 유사함을 확인할 수
있었다.

Table 2은 각 초위성체 유전표지의 유전자형 별 빈도를 토대로 하여 품종간의 유전적거리를 추정하여 제시하였다. 분석된 결과에 따르면 한우집단은 앵거스 집단과의 유전적거리 $(0.233$ $\pm 0.054)$ 가 홀스테인 집단과의 유전적거리(2.183 \pm 0.658 ) 보다 가까운 것으로 나타났으며 이에 비하여 앵거스 집단과 홀스테인 집단간의 유전 적거리 $(2.400 \pm 0.727)$ 는 상대적으로 상당히 먼 것으로 나타났다. 그림 1 에서 표 2 에 근거한 matrix를 이용하여 각 품종의 집단별 유전적 거 리와 유연관계를 분지도로 나타낸 것이다. 그 림 2는 각 개체들의 유전자형을 토대로 하여 집단내 개체들의 분포를 제시하였다. 홀스테인 의 경우 명확하게 하나의 군집을 형성하고 있 으며, 한우와 엥거스의 경우 각각의 군집 사이 에 몇몇의 개체들이 섞여 있는 것을 제외하면 명확하게 구분되어 있음을 확인하였다. 각 집 단의 유전적 구조가 명확하게 구분되어 있음은 분석집단간의 개체수의 차이가 있지만 각 개체 들이 집단의 유전적 특성을 잘 반영하고 있음 을 알 수 있었다. 이러한 결과로 미루어 볼 때 본 연구에서 활용된 10 종의 초위성체 유전표지 를 이용하여 품종 식별에 활용함에 있어 다소 어려움이 있겠으나 차후 지속적인 연구를 통해 각 품종의 유전적 특성을 잘 반영한 초위성체 유전표지의 선발이 이루어 진다면 품종의 식별 도 가능 할 것으로 생각된다. 본 연구에 활용된 3 개의 품종 이외에도 국내외에서 사육되는 육우 품종을 포함하고 품종간 교잡우 등에 대한 유전 적 특성 규명과 유전적 차별성의 확인이 가능한 다양한 유전자표지 (genetic marker)가 확보된다면 품종의 식별이 가능할 것으로 생각된다.

Table 2. Matrix of standard genetic distances (below diagonal) and standard error (above diagonal) estimated between 3 breeds based on 10 microsatellites.

\begin{tabular}{cccc}
\hline & HAN & ANG & HST \\
\hline \hline HAN & - & 0.054 & 0.658 \\
ANG & 0.233 & - & 0.727 \\
HST & 2.183 & 2.400 & - \\
\hline
\end{tabular}

HAN : Hanwoo, ANG : Angus, HST : Hostein. 


\section{IV. 요 약}

본 연구는 현재 수입되는 쇠고기 중 높은 비 중을 차지하고 있는 엥거스 품종과 육우로 사 육되는 홀스테인 품종을 대상으로 한우집단의 유전적 특성 및 비교대상 품종과의 유전적 차 별성을 검증하고자 실시하였다. 한우와 외래품 종간의 유전적 특성을 규명하기 위해 한우 300 두, 앵거스 80 두 그리고 홀스테인 50 두를 대상 으로 10 개의 초위성체 유전표지를 분석하였다. 대상 품종 집단별 유전적 특성, 집단내 유전적 변이성 및 유전적 차별성은 초위성체 유전표지 의 품종별 기대이형질성 (expected total heterozygosity; Exp-Hz), 관측된이형질성 (observed heterozygosity ; Obs.-Hz), 다형정보력 (polymorphism information content; PIC)에 근거하여 추 정되었다. 10 종의 초위성체유전표지 전체의 평 균 기대이형질성과 관측이형질성 한우집단에서 $0.772,0.733$ 으로 나타났으며, 앵거스집단에서는 각각 $0.759,0.707$ 및 홀스테인집단에서 각각 $0.741,0.720$ 으로 나타났다. 따라서 본 연구에서 분석된 대상 집단 중 한우집단이 다른 2 품종 집단 보다 집단 내 유전적 변이성이 높은 것으 로 나타났다. 초위성체 유전표지의 유전자형 별 빈도에 근거하여 품종간의 유전적거리를 추 정한 결과 한우집단과 앵거스 집단과의 유전적 거리 $(0.233 \pm 0.054)$ 가 홀스테인 집단과의 유전 적거리 $(2.183 \pm 0.658)$ 보다 가까운 것으로 나타 났다. 이에 비하여 앵거스 집단과 홀스테인 집 단간의 유전적거리 $(2.400 \pm 0.727)$ 는 상대적으로 먼 것으로 나타났다. 분석 대상 집단의 품종간 유전적 차별성을 개체들의 유전자형에 근거하 여 추정한 결과 홀스테인의 경우 명확하게 하 나의 군집을 형성하여 뚜렷한 품종차별성을 보 였으며, 한우와 엥거스의 경우 각각의 군집 사 이에 몇몇의 개체들이 섞여 있는 것을 제외하 면 명확하게 구분되어 있음을 확인하였다.

$$
\mathrm{V} \text {. 사 사 }
$$

본 연구는 농림기술관리센터의 "BT. IT 융합 기술을 활용한 한우 원산지추적 기술 개발” 과
제의 지원으로 이루어진 연구결과의 일부이며 연구비 지원에 감사를 드립니다.

\section{VI. 인 용 문 헌}

1. Arranz, J. J., Bayon, Y. and San Primitivo, F. 1996. Comparison of protein markers and microsatellites in differentiation of cattle populations. Anim. Genet. 27:415-419.

2. Barker, J. S. F., Tan, S. G., Selvaraj, O. S. and Mukherjee, T. K. 1997. Genetic variation within and relationships among populations of Asian water buffalo (Bubalus bubalis). Anim. Genet. 28: 1-13.

3. Bjornstad, G., Nilsen, N. O. and Roed, K. H. 2003. Genetic relationship between Mongolian and Norwegian horses. Anim. Genet. 34:55-58.

4. Blott, S. C., Williams, J. L. and Haley, C. S. 1999. Discriminating among cattle breeds using genetic markers. Heredity 82:613-619.

5. Hansen, C., Shrestha, J, N, B., Parker, R. J., Crow, G. H., McAlpine P. J. and Derr J. N. 2002. Genetic diversity among Canadienne, Brown Swiss, Holstein, and Jersey cattle of Canada based on 15 bovine microsatellite markers. Genome. 45:897-904.

6. Lee, C. and Pollak, E. J. 2002. Genetic antagonism between body weight and milk production in beef cattle. J. Anim. Sci. 80:316321.

7. Li, K., Chen, Y., Moran, C., Fan, B., Zhao, S. and Peng, Z. 2000. Analysis of diversity and genetic relationships between four Chinese indigenous pig breeds and one Australian commercial pig breed. Anim. Genet. 31:322-325.

8. Litt M, Luty J. A. A hypervariable microsatellite revealed by in vitro amplification of a dinucleotide repeat within the cardiac muscle actin gene. Am J Hum Genet. Mar; 44(3):397-401. 1989.

9. Luciana, P., Daniella, T., Andréa, P., Luiz, L. and Luciana, A. 2003. Genetic characterization of 
Aberdeen Angus cattle using molecular marker. Genetics and Molecular Biology. 26(2):133-137.

10. Martin-Burriel, I., Garcia-Muro, E. and Zaragoza, P. 1999. genetic diversity analysis of six Spanish native cattle breeds using microsatellites. Anim. Genet. 30:177-182.

11. Nei, M., Tajima, F. and Tateno, Y. 1983. Accuracy of estimated phylogenetic trees from molecular data. J. Mol. Evol. 19:153-170.

12. Ota, T. DISPAN. Pennsylvania State University. PA. USA. 1993.

13. Park, S. Microsatellite Toolkit For MS Excel 97 or 2000. (personnel communication). 2000.

14. Peelman, L, J., Mortiaux, F., Van Zeveren, A., Dansercoer, A., Mommens, G., Coopman, F., Bouquet, Y., Burny, A., Renaville, R. and Portetelle, D. 1998. Evaluation of the genetic variability of 23 bovine microsatellite markers in four Belgian cattle breeds. Anim Genet. Jun; 29(3):161-7.

15. Saitou, N. and Nei, M. The neighbor-joining method: A new method for reconstructing phylogenetic tree. Mol. Biol. Evol. 4:406-425. 1987.

16. 윤두학, 박응우, 이승환, 이학교, 오성종, 정일정, 홍기창. 2005. Microsatellite loci 분석에 의한 한 우와 타 품종간의 유전적 유연관계. 동물자원과 학회지. 47(3):341-354.

17. 임현태, 민희식, 문원곤, 이재봉, 김재환, 조인철, 이학교, 이용욱, 이정규, 전진태. 2005. 한우 생산 이력제에 활용 가능한 Microsatellite의 분석과 선 발. 동물자원과학회지. 47(4):491-500.

(접수일자 : 2008. 7. 2. / 수정일자: 2008. 10. 31./ 채택일자 : 2008. 11. 24.) 